\title{
PERANAN KEARIFAN LOKAL (LOCAL WISDOM) DALAM PENGEMBANGAN EKONOMI DAN PERBANKAN SYARIAH DI INDONESIA
}

\author{
Akhmad Mujahidin \\ Fakultas Syariah dan Hukum UIN Sultan Syarif Kasim Riau \\ Jl. HR Soebrantas 155 Km 15 Simpang Baru Panam Pekanbaru 28293 \\ e-mail: akhmad.mujahidin@gmail.com
}

\begin{abstract}
In the context of urban Indonesia economic community, several terms, such as paroan, prapatan, dan pertelon are quite popolar. Such terminology has influence economic activities whic have become tradition that supports profit sharing principles which is practiced by sharia banking. Such profit sharing practices basically aimes at creating justice and provide balances for economic users and their environments. Furthermore, profit sharing practices show partnership relation among enterprise practitioners; more than just the relationship between superiors and subordinators. This kind of spirit does not end in profit oriented only but also establishing buman based relationship which aimes at belping and caring one another. Dealing with the nature of the sprit above, sharia economic practitioners should have been energized and inspired and able to realize them in more real and synergical economic relationship. However, one important thing that they usually forget in developing business institution is lack of understanding toward the culture of the society where they build business, including sharia banking. Understanding toward local culture and wisdom of the society is one of the significant factors required in designing, harmonizing, and developing business. This implies that a busines institution should not aim at corporate oriented only. Infact, it should have relations of socioculture) and coorporate social responsibility.
\end{abstract}

Kata kunci: kearifan lokal, ekonomi syariah, bank syariah

\section{PENDAHULUAN}

Sebuah budaya lahir dari keluhuran nilai, - kemuliaan sikap, dan keagungan tradisi mayarakat yang berjalan secara berkelanjutan dan mengakar. Dalam prosesnya, budaya lahir dari adanya interaksi bahkan terkadang terjadi akulturasi antara keyakinan religi, sosial, dan tradisi masyarakat. Persentuhan tersebut melahirkan cara pandang, keyakinan, sikap dan ideologi yang heterogen dan dinamis. Oleh karena itu, kerangka yang digunakan untuk memahami budaya dalam komunitas tertentu harus juga memahami cara pandang, sikap, dan ideologi dimana komunitas masyarakat itu berada.

Keanekaragaman pola-pola adaptasi terhadap lingkungan hidup yang ada dalam masyarakat Indonesia yang diwariskan secara turun temurun menjadi pedoman dalam memanfaatkan sumberdaya alam. Kesadaran masyarakat untuk melestarikan lingkungan dapat ditumbuhkan secara efektif melalui pendekatan kebudayaan. Jika kesadaran tersebut dapat ditingkatkan, maka hal itu akan menjadi kekuatan yang sangat besar dalam pengelolaan lingkungan. Dalam pendekatan kebudayaan ini, penguatan modal sosial, 
seperti pranata sosial budaya, kearifan lokal, dan norma-norma yang terkait dengan pelestarian lingkungan hidup penting menjadi basis yang utama.

Seperti kita ketahui adanya krisis ekonomi dewasa ini, masyarakat yang hidup dengan menggantungkan alam dan mampu menjaga keseimbangan dengan lingkungannya dengan kearifan lokal yang dimiliki dan dilakukan tidak begitu merasakan adanya krisis ekonomi, atau pun tidak merasa terpukul seperti halnya masyarakat yang hidupnya sangat dipengaruhi oleh kehidupan modern. Maka dari itu kearifan lokal penting untuk dilestarikan dalam suatu masyarakat guna menjaga keseimbangan dengan lingkungannya dan sekaligus dapat melestarikan lingkungannya. Berkembangnya kearifan lokal tersebut tidak terlepas dari pengaruh berbagai faktor yang akan mempengaruhi perilaku manusia terhadap lingkungannya.

Dalam masyarakat beradab, budaya di bangun atas dasar konsensus nilai-nilai kearifan lokal. Jika kultur dan kearifan lokal dikaitan dengan aktivitas bisnis, maka ia menjadi sebuah entitas yang tidak bisa dipisahkan. Bisnis tidak bisa terlepas dari nilainilai budaya dan kehidupan sosial masyarakat yang dianut. Ia tidak bisa dipertentangkan, tetapi ia harus direlasikan atau bahkan diintegrasikan. Oleh karena itu, memahami nilai-nilai kearifan kultur lokal menjadi sangat signifikan dalam mengkonstruksi fundamental ekonomi syariah.

\section{KEARIFAN LOKAL DALAM PRESPEKTIF TEORI}

Salah satu ciri kearifan lokal adalah memiliki tingkat solidaritas yang tinggi atas lingkungannya. Dalam khasanah sosiologi Islam, Ibnu Khaldun dikenal sebagai peletak dasar teori solidaritas masyarakat atau dikenal dengan teori 'Ashâbiyat Teori ini merupakan pengejawantahan dari teori harmoni $\mathrm{ka}$ aljasad al-wahid dalam ajaran Islam, yang menggambarkan kelaziman saling melindungi dan mengembangkan potensi serta saling mengisi dan membantu di antara sesama. Melalui teori harmoni $k a$ al-jasad al-wahid dimisalkan kehidupan komunitas muslim itu dengan ka al-bunyan yasuddu ba'duha ba'dla bagaikan sebuah bangunan, yang antara elemen bangunan yang satu dengan yang lainnya saling memperkokoh memperkuat (lbnu Khaldun, 1986: t.h.). Teori 'Ashâbiyatsolidaritas kelompok dan konsep ta'âwwun alihsan itu didasarkan atas pemikiran ajaran Islam, yang di dalamnya terkandung norma akidah dan syari'at (Muhamad Syaltut, 1959: t.h.). Unsur syari'at itu merupakan norma sentral bagi kaum Muslimin. Karena di dalamnya memuat ragam aturan, termasuk tata cara transaksi ekonomi yang sesuai dengan kaidah-kaidah syariah.

Ibnu Qayyim menjelaskan pengaruh motif suatu tindakan, baik yang berhubungan dengan transaksi bisnis. Kaidah syariah yang tidak dapat diabaikan adalah tujuan dan i'tikad yang berpengaruh terhadap transaksi bisnis. Tujuan dan i'tikad sangat menentukan apakah suatu tindakan itu jatuh pada hal yang halal atau haram, sah atau batal, dan maksiat atau taat (Ibn Qayyim al-Jawziyyah, t.th.: 108).

David Mc. Clelland dengan teorinya Need for Achievement menyatakan bahwa kemajuan ekonomi suatu masyarakat dapat dijelaskan dengan tinggi rendahnya motif berprestasi pada suatu masyarakat tertentu. Perkembangan ekonomi masyarakat yang memiliki motif prestasi tinggi akan lebih pesat dari perkembangan masyarakat dengan motif prestasi rendah, karena dalam masyarakat yang para anggotanya memiliki motif prestasi tinggi akan lebih banyak dijumpai berbagai macam wirausaha yang berhasil dan mereka itu yang menjadi pendorong utama pembangunan ekonomi (Doyle Paul Johnson, 
1988: 283). Kelemahan dari teori ini adalah mengabaikan adanya interaksi sosial antara individu dengan individu lainnya.

Sedangkan Harun Nasution mengemukakan bahwa suatu pandangan yang menyatakan manusia adalah bagian dari alam akan menyebabkan manusia lebih menerima nasibnya tanpa usaha yang maksimal. Manusia akan menyesuaikan dirinya dengan alam atas desakan kondisi alam itu sendiri dengan bekal etos kerja yang dimiliki. Sedangkan pandangan yang menyatakan bahwa alam diciptakan untuk memenuhi kebutuhan manusia akan membawanya selalu proaktif meningkatkan taraf hidupnya (Harun Nasution, 2002: 31).

Teori-teori tersebut menurut Akhmad Mujahidin (Akhmad Mujahidin, 2013: 127). menunjukkan bahwa karakteristik manusia yang mempunyai motivasi tinggi akan tampak dalam tingkah laku yang dilandaskan pada suatu keyakinan yang sangat mendalam bahwa apa yang dilakukannya merupakan bagian dari ibadah kepada Allah. Bekerja merupakan suatu panggilan yang sangat mulia dan perintah dari Allah yang menempatkan dirinya sebagai makhluk pilihan sehingga tumbuh dalam dirinya kehati-hatian, menghargai waktu, hemat, produktif, dan memperlebar sifat kasih sayang sesama manusia.

Solidaritas kelompok sebagai dasar kehidupan yang dilandasi oleh iman dan akhlak mulia seperti yang dicontohkan Rasulullah Saw dapat memberikan implikasi terhadap tatanan kerja sama kemanusiaan (ta'âwun al-ihsan). Apabila teori tersebut dihubungkan dengan kegiatan ekonomi, maka akan dapat mendorong masyarakat untuk bersatu dan aktif partisipatif dalam proses pembangunan ekonomi syariah.

Motivasi seseorang untuk ambil bagian dalam suatu proses kehidupan sosial sangat beragam sebagaimana halnya motivasi seseorang untuk melaksanakan ibadah, seperti shalat, puasa, dan sebagainya. Keragaman motivasi atau latar belakang niat seseorang dalam bertindak adalah suatu hal yang tidak terelakkan dan secara hukum tidak dipersalahkan. Sejarah menjelaskan kepada kita, ketika Nabi Muhammad Saw berhijrah bersama para pengikutnya, beliau mengatakan bahwa motivasi dan keikutsertaan para pengikutnya itu beragam, ada yang bermotifkan kekayaan, dan ada juga karena dorongan wanita yang ingin dinikahinya. Semuanya itu dibenarkan, hanya saja kualitas partisipasi yang terbaik dan tertinggi dalam pandangan agama Islam adalah karena Allah Swt. Hadis yang berbunyi: innama al-'amal bi al-niyyât dan seterusnya, membenarkan keragamaan motivasi tindakan. Oleh karena itu, masalah partisipasi masyarakat dalam ekonomi syariah pun demikian. Motivasi partisipasi masyarakat itu harus diciptakan. Menurut Abdurrahman bin Abd al Salam al Syafi'i dalam kitab Nuzhat al Majalis wa Muntakhab al Nafais bahwa motivasi seseorang untuk melaksanakan muamalat sebagaimana juga melaksanakan ibadah selalu beragam. Minimal ada tiga motivasi utama: 1). Motivasi ekonomi, yakni ingin mendapat imbalan material yang bernilai; 2). "takut" mendapat ancaman "akhirat" dan ingin "surga"; 3). Ikhlas bermuamalat atas landasan iman tauhid yang amat murni; lillahi ta'ala (Abdurrahman bin Abd al Salam al Syafi'i, 2005: 7).

Dengan demikian dapatlah dikatakan di sini bahwa akhlak yang sangat ditekankan Alquran dan Hadis harus mendapat perhatian khusus yang diwujudkan sebagai dasar perilaku secara umum, khususnya masalah ekonomi. Pandangan yang bertumpu pada kekuatan moral (moral force) akan berpeluang mengantarkan manusia pada kebahagiaan, ketenteraman, dan kesejahteraan. 
Islam dalam pandangan ekonominya tidak terlepas dari pandangan moral. Moral harus dipertimbangkan sejak awal proses berbisnis hingga target utama dari bisnis yang bersangkutan. Sebab penegakan moral adalah bagian penting dari syariah. Dalam Islam tidak ditemukan pemisahan nilai moral dengan praktek hukum. Oleh karena itu, ada orang yang sangat pintar keluar dari jeratan hukum formal tetapi ia tidak dapat keluar dari nilai moral yang bersemayam di dalam hatinya. Dari mana nilai moral itu? Tentu saja keluar dari akidah yang ditumbuhsuburkan oleh ibadah.

Ada perbedaan yang signifikan antara Undang-undang formal dengan nilai-nilai moral. Perbedaannya yang sangat signifikan adalah hukum formal hanya mengatur perilaku manusia yang menyembul ke permukaan saja tidak menyentuh ke dalam hati. Undang-undang formal hanya memberi sanksi terhadap pelanggar atas tindakan melawan hukum, sedangkan moral tidak, namun moral menembus ke dalam sampai melihat hal yang bersifat niat sekalipun. Misalnya motif suatu tindakan: apa motifnya dan apa pula targetnya, maka di sinilah moral memberikan penilaian ('Abd al-Hayyi Hijazi, 1987: 165).

Lebih lanjut Hijazi menyatakan bahwa Undang-undang harus sama dengan nilai akhlak. Namun demikian, bukan berarti setiap Undang-undang yang tidak sama dengan akhlak tidak dianggap sebagai Undangundang. Sebab antara keduanya tidak ada kelaziman. Keduanya merupakan hal yang berbeda. Oleh karena itu, Undang-undang yang diintegrasikan dengan akhlak akan efektif dalam menekan kejahatan, bahaya, maupun gejolak sosial ('Abd al-Hayyi Hijazi, 1987: 166).

Dalam Islam antara Undang-undang dan moral tidak dapat dipisahkan. Misalnya, kaidah moral mencermati sampai ke motif tindakan. Hanya saja perlu diingat bahwa ada motif perilaku yang bertentangan dengan hukum akhlak yang berakibat pada batalnya suatu akad. Sebagai contoh, wasiat dengan motif menggagalkan hak pewaris, maka wasiat dengan motif seperti ini batal. Demikian pula talak demi menghalangi istri mendapatkan warisan juga dianggap batal. Dengan demikian semakin jelas bahwa hukum moral harus berintegrasi dengan hukum formal.

Seperti yang telah dikemukakan sebelumnya tentang teori Ibnu Qayyim, David Mc. Clelland, dan Harun Nasution, menunjukkan bahwa karakteristik manusia yang mempunyai motivasi tinggi akan tampak dalam tingkah laku yang dilandaskan pada suatu keyakinan yang sangat mendalam bahwa apa yang dilakukannya merupakan bagian dari ibadah kepada Allah. Bekerja merupakan suatu panggilan yang sangat mulia dan perintah dari Allah yang menempatkan dirinya sebagai makhluk pilihan sehingga tumbuh dalam dirinya kehati-hatian, menghargai waktu, hemat, produktif, dan memperlebar sifat kasih sayang sesama manusia.

Dengan demikian dapatlah dikatakan di sini bahwa akhlak yang sangat ditekankan Alquran dan Hadis harus mendapat perhatian khusus yang diwujudkan sebagai dasar perilaku secara umum, khususnya masalah ekonomi. Pandangan yang bertumpu pada kekuatan moral (moral force) akan berpeluang mengantarkan manusia pada kebahagiaan, ketenteraman, dan kesejahteraan. Untuk itulah, dalam Islam terdapat petugas khusus yang disebut muhtasib. Petugas ini secara khusus dibentuk untuk mengawasi moral masyarakat sehingga tercipta ketertiban dan kesejahteraan umum yang diharapkan oleh seluruh lapisan masyarakat. 


\section{HISTORISITAS HUKUM ISLAM SEBAGAI WUJUD KEARIFAN LOKAL DI INDONESIA}

Hukum Islam merupakan kumpulan dari aturan Allah dan Rasul-Nya yang mengatur kehidupan seluruh umat manusia sesuai dengan misi Islam sebagai agama universal (rahmatan li al-'alamin). Hal ini menunjukkan bahwa hukum Islam tidak hanya berlaku bagi orang Islam, tetapi juga bagi orang-orang non-Islam sekalipun. Oleh karena itu, dengan karakteristik universal ini, maka hukum Islam menempati posisi yang penting dan strategis dalam prespektif umat Islam (Taufik Adnan Amal, 1994: 33). Hal ini menunjukkan bahwa sangat mustahil orang bisa memahami Islam tanpa memahami hukum Islam. Dalam kasus Indonesia, sejak Islam masuk ke nusantara (G.W.J. Drewes, 1989: 9) dan menjadi agama rakyat Melayu, hukum Islam sudah memainkan peranan penting dalam kehidupan rakyat Indonesia. Hal ini bisa dilihat dalam periode kerajaan Islam awal (Ahmad Rofiq, 1995: 12). bahkan hukum Islam dijadikan sebagai hukum resmi kerajaan seiring dengan ditetapkannya Islam sebagai agama resmi kerajaan (Rachmat Djatnika dalam Abdurrahman Wahid, 1991: 230). Kondisi seperti ini dapat kita lihat dan rasakan bahwa hukum Islam sampai sekarang dapat berperan aktif dalam tatanan kehidupan bermasyarakat dan bernegara yang berlaku baik secara normatif maupun yuridis formal di Indonesia.

Indonesia adalah negara hukum yang sejak berdirinya sudah berkeinginan membentuk hukum nasionalnya sendiri. Sorotan banyak muncul ketika pemerintah mengeluarkan Undang-Undang No. 1 tahun 1946 yang isinya memberlakukan UndangUndang Hukum Pidana Hindia Belanda (Sucipto, 1993: 64). Apa yang dilakukan pemerintah saat itu merupakan hal yang wajar karena umur negara Indonesia yang masih berada dalam hitungan bulan dan kesibukan pemerintah dalam berbagai hal untuk mempertahankan kemerdekaan, maka upaya menerbitkan Undang-undang tersebut dapat dipahami sebagai pengisi kekosongan hukum.

Perkembangan selanjutnya menunjukkan bahwa dalam rangka pembinaan hukum nasional, hukum Islam merupakan aset penting yang sangat berharga karena selain mayoritas penduduk Indonesia beragama Islam juga karena hukum Islam merupakan sub-sistem hukum nasional Indonesia berdampingan dengan hukum Adat dan hukum Barat sejak Dekrit Presiden 5 Juli 1959 (Juhaya S. Praja, 1994: xi-xii).

Dalam kaitan inilah, kajian tentang penegakan syariat ini sangat penting dilakukan dengan pertimbangan bahwa pada saat ini upaya serius yang dilakukan di negara-negara berpenduduk muslim, tidak terkecuali Indonesia, adalah selain mengejar ketertinggalan dalam bidang ilmu pengetahuan dan teknologi, juga secara bertahap memperbarui hukum, yang sebagiannya masih merupakan peninggalan kolonial. Dalam upaya ini, para pakar, akademisi, dan praktisi hukum Islam dituntut untuk memberikan solusi agar tercipta hukum nasional yang bisa mengayomi segenap lapisan masyarakat.

\section{KEDUDUKAN HUKUM ISLAM DI INDONESIA}

Kedudukan hukum Islam dalam negara Republik Indonesia secara eksplisit tercantum dalam pasal 29 UUD 1945 yang menyatakan bahwa negara berdasarkan atas Ketuhanan Yang Maha Esa dan menjamin kemerdekaan masing-masing penduduk untuk melaksanakan ibadah berdasarkan agama dan kepercayaannya (Redaksi Sinar Grafika, 1999: 
16). Menurut Hazairin, kaidah fundamental dalam pasal tersebut dapat ditafsirkan sebagai berikut:

1. Dalam negara RI tidak boleh ada atau tidak boleh berlaku hukum yang bertentangan dengan kaidah-kaidah agama yang berlaku bagi pemeluk agama.

2. Negara wajib menjalankan syariah semua agama yang berlaku di Indonesia, kalau untuk menjalankan syariah itu memerlukan bantuan kekuasaan Negara (Muhammad Daud Ali, 1997: 45).

Syariah yang tidak memerlukan kekuasaan negara untuk melaksanakannya karena dapat dijalankan sendiri oleh setiap pemeluk agama yang bersangkutan seperti salat dan puasa bagi umat Islam, menjadi kewajiban pribadi pemeluk agama itu sendiri untuk menjalankannya menurut ketentuan agamanya masing-masing.

Pasal 29 UUD 1945 ini mempunyai tiga muatan makna. Pertama, negara tidak boleh membuat peraturan perundang-undangan atau melakukan kebijakan-kebijakan yang bertentangan dengan dasar keimanan kepada Tuhan Yang Maha Esa. Kedua, negara berkewajiban membuat peraturan perundangundangan atau melakukan kebijakan-kebijakan bagi pelaksanaan wujud rasa keimanan kepada Tuhan Yang Maha Esa dari segolongan pemeluk agama yang memerlukannya. Ketiga, negara berkewajiban membuat peraturan perundang-undangan yang melarang siapa pun melakukan pelecehan terhadap ajaran agama (Hartono Mardjono, 1997: 28).

Dengan tiga makna ini dapat dipahami bahwa negara berkewajiban secara aktif melakukan upaya-upaya agar setiap penduduk dapat memeluk agama dan beribadat menurut agama dan kepercayaannya itu. Keaktifan negara di sini adalah untuk menjamin agar setiap penduduk dapat merdeka menentukan pilihan atas agama yang hendak dipeluknya dan jaminan agar setiap penduduk dapat menjalankan ibadahnya menurut agama dan kepercayaan yang ditetapkan oleh agama yang dipeluknya. Tetapi keaktifan negara tidak boleh mencampuri aturan-aturan internal (Yusril Ihza Mahendra, 1996: 119-120) yang telah ditentukan oleh masing-masing agama penduduknya.

\section{REALITAS HUKUM ISLAM DI INDONESIA}

Bagi umat Islam, pelaksanaan isi pasal 29 tersebut telah terwujud dalam bentuk UU No. 1 tahun 1974 tentang Perkawinan, UU No. 7 tahun 1989 tentang Peradilan Agama, Inpres No. 1 tahun 1991 tentang Kompilasi Hukum Islam, UU No. 7 tahun 1992 tentang Perbankan, UU No. 17 tahun 1999 tentang Penyelenggaraan Ibadah Haji, UU No. 38 tahun 1999 Pengelolaan Zakat, UU. No 44 tahun 1999 tentang Penyelenggaraan Keistimewaan Provinsi DI Aceh, dan UU. No. 18 tahun 2001 tentang Otonomi Khusus Provinsi DI Aceh sebagai Provinsi Nangroe Aceh Darussalam (Muchsin, 2003: 18-19). Selain itu juga telah lahir UU No. 21 tahun 2008 tentang Perbankan Syariah, Peraturan Bank Indonesia (PBI) UU Produk Halal dan inisiatif-inisiatif lain tentang tematema hukum Islam.

Realitas ini menunjukkan bahwa negara Indonesia telah memberikan ruang gerak yang cukup bagi terlembaganya hukum Islam dalam sistem hukum nasional. Dengan demikian setiap muslim dapat sepenuhnya menjalankan kegiatan sesuai dengan ajaranajaran Islam apabila mereka menghendaki. Jika dikalaborasi lebih lanjut maka dalam kegiatan di bidang muamalat seperti jual-beli, sewamenyewa, dan lain-lain juga dapat dilakukan sepenuhnya berdasarkan hukum Islam, sehingga seluruh kegiatan dalam kehidupan muslim akan tunduk kepada hukum Islam. Logikanya apabila dalam bidang perkawinan, 
kewarisan, dan wakaf sudah ada Kompilasi Hukum Islam, mengapa dalam bidang muamalat seperti jual-beli belum ada Kompilasi Hukum Islam di bidang muamalat. Keberadaan kompilasi hukum di bidang muamalat ini dirasakan sangat mendesak untuk segera diwujudkan ('Abd al-Rahman Taj, 1953: 8-11) karena ekonomi merupakan salah satu bidang yang sangat menentukan kualitas hidup umat muslim. Saat ini, telah muncul KHES oleh Mahkamah Agung RI.

Negara Indonesia yang berfalsafah Pancasila melindungi agama, penganut agama, bahkan berusaha memasukkan ajaran dan hukum agama Islam dalam kehidupan berbangsa dan bernegara. Mohammad Hatta (wakil Presiden RI I) menyatakan bahwa dalam pengaturan negara hukum Republik Indonesia, syariah Islam berdasarkan Alquran dan Hadis dapat dijadikan peraturan perundangundangan Indonesia sehingga orang Islam mempunyai sistem syariah yang sesuai dengan kondisi Indonesia (Ichtijanto SA, 1996: 178). Hal ini menunjukkan bahwa Hukum Islam mempunyai peluang yang besar untuk diberlakukan dalam sistem hukum nasional, karena Indonesia adalah negara yang berdasarkan atas hukum (rechtsstaat), tidak berdasarkan atas kekuasaan belaka (machtsstaat) (Redaktur Sinar Grafika, Amendemen, 24). Sumber dari segala sumber hukum nasional adalah Pancasila, karena itu berlaku pula hukum agama dan toleransi antar umat beragama dalam bermasyarakat, berbangsa, dan bernegara (Muchsin, 2003: 29).

Indikasi bahwa Hukum Islam di Indonesia dapat diakomodir dalam sistem hukum nasional dapat dilihat dari fakta-fakta berikut ini:

1. Undang-undang yang sudah ada dan berlaku saat ini, seperti UU Perkawinan, UU Peradilan Agama, dan lain-lain merupakan modal bagi terbentuknya Undang-undang lainnya.

2. Jumlah penduduk Indonesia yang mencapai lebih kurang $95 \%$ beragama Islam akan memberikan pertimbangan yang sangat signifikan dalam mengakomodasi kepentingannya.Demi terselenggaranya pelaksanaan hukum yang lebih efektif dan efisien, maka solusi yang tepat adalah memenuhi aspirasi mayoritas penduduk Indonesia yang beragama Islam ini.

3. Kesadaran umat Islam dalam praktek sehari-hari. Banyak aktifitas keagamaan masyarakat selama ini yang merupakan cerminan dari kesadaran mereka menjalankan syariah atau Hukum Islam seperti pembagian zakat dan waris.

4. Politik pemerintah atau political will dari pemerintah dalam hal ini sangat dibutuhkan. Tanpa adanya kemauan politik dari pemerintah, mustahil Hukum Islam dapat menjadi bagian dari tata hukum di Indonesia (Muchsin, 2003: 30-31).

Dengan melihat indikator-indikator tersebut, maka diperlukan keterlibatan para akademisi perguruan tinggi, baik di fakultas hukum maupun fakultas syariah agar dapat mengembangkan penelitian yang pada akhirnya dapat dijadikan pedoman bagi praktisi hukum dalam mengambil keputusan yang terkait dengan persoalan hukum yang hidup dan terjadi di dalam masyarakat.

Prakondisi yang dimaksud adalah upaya untuk mencegah kejahatan yang dilakukan oleh umat Islam melalui langkah-langkah sebagai berikut:

1. Pencegahan melalui aspek akidah. Akidah yang kuat dapat membuat orang merasa diawasi oleh Tuhannya, sehingga ia mampu melakukan self control terhadap perbuatan yang dilakukannya.

2. Pencegahan dari aspek ibadah. Ibadahibadah yang diwajibkan oleh agama bila dilakukan dengan baik akan berdampak 
positif bagi pelakunya. Shalat dapat mencegah perbuatan keji dan munkar (terdapat dalam alquran surat al-Ankabut ayat 45). Dalam shalat, seseorang harus meletakkan anggota badan yang paling terhormat, yakni wajahnya, ke lantai agar benih-benih kesombongan dapat tercabut dari jiwanya. Demikian pula zakat dapat dijadikan instrumen pembersih (terdapat dalam Alquran surat at-Taubah ayat 103) karena dapat membersihkan manusia dari kekikiran dan ketamakan. Realitas menunjukkan bahwa kejahatan lebih banyak dilakukan oleh mereka yang tidak begitu peduli dengan kualitas ibadahnya.

3. Pencegahan dari segi keadilan sosial. Dalam arti, setiap warga negara telah diberi kesempatan yang mudah untuk memenuhi kebutuhannya dengan cara yang halal dan tertutup dihadapannya kesempatan untuk berbuat yang tidak halal atau yang membuatnya tertarik dengan hal-hal yang tidak halal. Pencegahan seperti ini pernah dijadikan klausul tidak diterapkannya hukum potong tangan bagi pencuri ketika paceklik pada masa 'Umar bin Khattab.

4. Pencegahan melalui amar ma'ruf nahi munkar yang seharusnya menjadi budaya di kalangan masyarakat muslim karena hal ini merupakan titik sentral dari ajaran agama. Pelaksanaan amar ma'ruf nahi munkar secara rapi dan terarah, apalagi dilembagakan jabatan muhtasib secara resmi oleh negara, akan dapat menjamin ketentraman, keadilan, dan hal-hal kondusif lain yang diharapkan oleh seluruh masyarakat.

Prakondisi tersebut merupakan upaya awal untuk menguji situasi dan kondisi moral masyarakat muslim di Indonesia. Apabila prakondisi itu telah diciptakan, sementara kejahatan dan kerusakan moral tetap terjadi, maka tidak ada alasan untuk menolak pelembagaan hukum Islam. Pelembagaan dan penerapan hukum Islam dapat dipastikan akan meminimalisir tindak kejahatan yang terjadi. Hal ini terbukti bahwa pada zaman Nabi Muhammad Saw hukuman zina hanya dilaksanakan satu kali karena pengakuan pelakunya dan ia meminta untuk dirajam. Ini berarti penerapan dan pelembagaan hukum Islam dapat dijadikan alternatif yang tepat untuk menekan angka kejahatan

\section{KEARIFAN LOKAL: SEBUAH FAKTA DI INDONESIA}

Dalam kultur ekonomi masyarakat Indonesia di pedesaan dikenal beberapa istilah seperti paroan, prapatan, dan pertelon. Terminologi tersebut tidak hanya menyemangati bagaimana aktivitas ekonomi yang sudah lama mengakar di masyarakat, yang menjungjung tinggi prinsip-prinsip bagi hasil sebagaimana dipraktekkan di bank syariah. Pola bagi hasil yang telah lama tumbuh dimasyarakat, sebenarnya mengarah pada penciptaan keadilan dan memberikan keseimbangan terhadap pelaku ekonomi (economic users) dengan lingkungannya. Bahkan tidak hanya itu, pola bagi hasil juga menyimpan semangat-relasi kemitraan antara pelaku usaha, dari pada sekedar hubungan antara majikan dan bawahan. Semangat kemitraan inilah yang akan mengantarkan para pelaku usaha, tidak hanya sekedar hubungan usaha yang bersifat profit oriented, tetapi pada hakekatnya merupakan kerjasama kemanusiaan, satu sama lainnya akan saling memperhatikan dan saling membantu.

Adanya relasi kultur aktivitas ekonomi masyarakat dengan ekonomi syariah seharusnya menjadi energi dan inspirasi, bagaimana para pelaku ekonomi syariah dapat mengejawantahkan semangat kultur pada hubungan ekonomi yang lebih riil dan bersinergi. Namun, hal yang sering terlupakan 
dalam pembangunan institusi bisnis adalah kurangnya pemahaman terhadap kultur masyarakat di mana institusi bisnis tersebut berada, tidak terkecuali bank syariah yang merupakan bagian dari entitas bisnis itu sendiri. Pemahaman atas kultur masyarakat dan kearifan lokal merupakan salah satu faktor signifikan sebagai prasyarat untuk mendesain, menyelaraskan dan mengembangkan bisnis yang kita jalankan. Dengan demikian, suatu institusi bisnis tidak hanya berorientasi perusahaan (corporate oriented) tetapi, ia mempunyai keselarasan sosio-kultur (relations of socio-culture) dan tanggung jawab sosial (coorporate social responsibility).

Selain itu, Pasal 32 UUD 1945 yang diamandemen pada kali yang keempat tersebut di atas, pada pasal (1) memberikan arahan bahwa negara memajukan kebudayaan nasional Indonesia di tengah peradaban dunia, dengan menjamin kebebasan masyarakat dalam memelihara dan mengembangkan nilainilai budayanya. Artinya bangsa Indonesia sadar bahwa budaya nasional mereka berada di dalam arus globalisasi, namun untuk mempertahankan jati diri masyarakat diberi kebebasan dan bahkan sangat perlu memelihara dan mengembangkan nilai-nilai budaya (tradisi atau etniknya). Pada pasal (2) pula, negara menghormati dan memelihara bahasa daerah sebagai kekayaan budaya nasional. Dengan demikian jelas bagi kita bahwa bahasa daerah (dan juga kesenian atau budaya daerah/etnik) sebagai bahagian penting dari kebudayaan nasional. Artinya kebudayaan nasional dibentuk oleh kebudayaan (bahasa) etnik atau daerah--bukan kebudayaan asing. Dengan demikian jelas bahwa Indonesia memiliki budaya nasional, yang berasal dari budaya etnik, bukan penjumlahan budaya etnik.

\section{PENGEMBANGAN PERBANKAN SYARIAH}

Untuk merancang kultur ekonomi syariah harus memperhatikan nilai-nilai religi, karakteristik masyarakat, dan tingkat pemahaman kesadaran masyarakat atas keyakinan yang dianut, termasuk keyakinan atas ekonomi syariah sebagai sistem ekonomi yang lahir dari prinsip-prinsip keagungan syariah.

Di Indonesia, pemahaman atas syariah Islam memiliki tafsir yang berbeda, tidak hanya dalam ibadah saja (hal yang menyangkut khilafiyah), dalam persoalan ekonomi-pun tidak jauh berbeda, masing-masing memiliki cara pandang sendiri dan mazhab sendiri. Sebagai contoh, persoalan hukum bunga bank, tafsir atas bunga bank sangat beragam, ada yang menghalalkan, dengan alasan bahwa bunga bank konvensional tidak memberatkan. Ada juga yang mengharamkan dengan alasan bahwa bunga bank termasuk riba.

Adanya pemahaman yang berbeda atas bunga bank, diyakini berpengaruh terhadap cara pandang dan perilaku/motif ekonomi yang berbeda pula. Bagi mereka yang meyakini bahwa bunga bank haram, maka ia akan lebih memilih menyimpan dananya di bank syariah, begitu sebaliknya.

Faktor pemahaman yang berbeda ini secara tidak langsung berpengaruh pada perilaku masyarakat untuk berinteraksi dan menyimpan dananya di bank syariah. Pemahaman atas bunga bank yang berbeda tidak bisa paksakan menjadi pemahaman yang satu. Meskipun para ulama dalam hal ini Majelis Ulama Indonesia (MUI) mengeluarkan fatwa di awal 2004 tentang haramnya bunga bank.

Penjelasan tentang haramnya bunga bank harus mendapatkan perhatian utama. Masalah yang pertama kali harus kita putuskan adalah apakah bunga itu merupakan pembayaran yang beralasan? Apakah para 
kreditor itu adil apabila menuntut untuk membayar bunga atas hutang yang diberikan? Dan adilkah jika penghutang dituntut harus membayar bunga terhadap pemberi pinjaman sesuatu yang melebihi pinjaman pokok? Jawaban atas pertanyaan-pertanyaan tersebut akan menyelesalkan separuh dari masalah bunga. Jika dapat ditunjukkan bahwa bunga tidak dapat dibenarkan baik oleh akal maupun keadilan, lalu mengapa bunga masih menjadi perdebatan. Mengapa peraturan yang tak beralasan tersebut tetap dibiarkan berlangsung berada di tengah masyarakat?

Terdapat perbedaan pendapat yang menyolok di antara para ahli yang mendukung doktrin bunga, yaitu untuk apakah bunga itu dibayarkan? Sebagian mengatakan bunga itu merupakan harga, tetapi harga untuk apa? Benda berharga apakah yang dibayar oleh kreditor sehingga ia menuntut imbalan uang setiap bulan ataupun setiap tahun? Para pelopor institusi bunga mendapat kesulitan besar untuk memperoleh kesepakatan dalam masalah ini.

Pelopor teori piutang menanggung Resiko ini menegaskan bahwa kreditor menanggung resiko karena meminjamkan modalnya. Ia sendiri menangguhkan keinginannya semata-mata untuk memenuhi keinginan orang lain. Ia meminjamkan modalnya yang mestinya dapat mendatangkan keuntungan. Jika penghutang menggunakan modalnya itu untuk memenuhi keinginan pribadinya, ia harus membayar sewa atas modal yang dipinjam itu, sama halnya ia membayar sewa terhadap sebuah rumah atau perabotan maupun kendaraan. Sewa merupakan kompensasi terhadap resiko yang ditanggung oleh kreditor karena memberi pinjaman dan sekaligus imbalan karena ia memberikan pinjaman modalnya. Dan apabila peminjam menginvestasikan modalnya pada usaha-usaha yang dapat memberikan keuntungan, maka tidak berlebihan dan adil apabila pemberi pinjaman menuntut sebagian dari keuntungan tersebut.

Marilah kita analisa maksud "resiko". Memang benar bahwa pemberi pinjaman menanggung resiko serta mengorbankan sesuatu apabila ia meminjamkan modalnya kepada peminjam; tetapi dengan cara apapun, hal ini tidak memberikan hak kepada pemberi pinjaman untuk mengenakan harga 5 atau 10\% pertahun atas resiko atau pengorbanannya. Pemberi pinjaman mempunyai alasan yang baik untuk menahan jaminan atas harta penghutang atau meminta garansi terhadap resiko yang ditanggungnya jika ia tidak mau melakukan di antara pilihan tersebut; tidak mau mengambil resiko sama sekali dan menolak untuk memberikan pinjaman.

Tetapi resiko itu sendiri bukanlah barang komersial yang memunculkan harga, juga bukan sebagai perabotan atau kendaraan yang memungkinkan mendatangkan sewa. Pinjaman dapat dikatakan sebagai pengorbanan sepanjang pinjaman itu tidak dianggap sebagai dagangan karena pinjaman tidak dapat dianggap sebagai pengorbanan maupun barang dagangan. Jika seseorang melakukan pengorbanan moral, maka ia harus puas dengan apa yang ia peroleh secara moral; apabila ia tidak boleh mengatakan sebagai pengorbanan melainkan harus sebagai suatu bisnis. Dan apabila ia menuntut imbalan ekstra yang melebihi modal pokok pertahun atau perbulan, ia harus memberikan alasan atas tindakannya itu dan menjelaskan mengapa ia meminta imbalan semacam itu?

Marilah kita meneliti dua aspek bunga sebagai imbalan karena menahan diri atau sebagai bayaran sewa. Apakah bunga merupakan imbalan karena menahan diri? Sesungguhnya kreditor hanya meminjamkan sejumlah uang yang berlebih dari yang ia perlukan dan yang tidak digunakan sendiri. Oleh karena itu, tidak boleh dikatakan sebagai imbalan karena ia tidak menahan diri dari 
sesuatu yang memungkinkan dirinya menuntut imbalan.

Apakah bunga itu dikenakan sebagai pembayaran sewa? Sewa itu hanya dikenakan terhadap barang-barang, seperti rumah, perabotan, alat transportasi dan sebagainya, yang digunakan habis, rusak dan kehilangan sebagian dari nilainya selama digunakan. Biaya sewa yang dibayarkan itu layak terhadap barang yang susut, rusak dan memerlukan biaya perawatan terhadap barang tersebut. Tetapi barang-barang seperti makanan, emas, perak atau uang tidak dapat dikategorikan kedalamnya dan oleh karenanya sewa atasnya tidak punya dasar.

Sebagian besar para kreditor mengatakan bahwa ia memberikan kesempatan kepada peminjam untuk mencari keuntungan dari modalnya sehingga dengan begitu ia harus memberikan sebagian keuntungannya. Tetapi terhadap pinjaman konsumsi, alasan ini tidak berlaku karena peminjam biasanya orang miskin yang mengambil pinjaman untuk mengatasi masa-masa sulit dan tidak ada keuntldngan yang dapat dlbagikan.

Di dalam pinjaman produktif, terdapat dua kemungkinan yaitu memperoleh keuntungan atau menderita kerugian. Jika peminjam menjalankan bisnisnya mengalami kerugian, bagaimana dan dengan landasan apa kreditor dibenarkan menarik keuntungan tetap secara bulanan atau tahunan dari peminjam? Dan apabila keuntungan yang diperoleh sama atau kurang dari besarnya bunga setiap bulan atau tahun, maka bagaimana kreditor dibenarkan untuk mengambil bagian sedangkan ia sendiri tidak melakukan apaapa; sementara peminjam yang bekerja keras, meluangkan waktunya, tenaga, kemampuan dan modal pribadinya, setelah pengorbanan itu semua, tidak memperoleh apa-apa.

Kalaupun keuntungan yang diperoleh peminjam itu lebih besar dari jumlah bunga yang harus dibayarkan, tidak dibenarkan baik dengan akal, rasa keadilan, prinsip-prinsip perdagangan dan ekonomi bahwa pedagang, industrialis, petani serta faktor-faktor produksi lainnya, yang telah menghabiskan waktu, tenaga, kemampuan dan sumber lain dari pada jasmani dan mentalnya, untuk mengeluarkan atau menyediakan barangbarang kebutuhan masyarakat, yang kemungkinan memperoleh keuntungannya tidak tetap, sedangkan kapitalis memperoleh jaminan bunga yang tetap dan pasti. Semua pihak mempunyai resiko menderita kerugian, tetapi pemilik modal memiliki jaminan bunga yang pasti. Besarnya keuntungan bagi semua agen mengalami naik turun sejalan dengan perubahan harga tetapi bunga bagi kapitalis tetap saja dan dibayar secara tetap setiap bulan atau setiap tahun dalam keadaan bagaimanapun.

Tetapi jika kreditor menginginkan modalnya harus diinvestasikan pada usahausaha yang menguntungkan sehingga memungkinkan ia memperoleh keuntungan, satu-satunya cara yang wajar dan praktis baginya adalah dengan memasuki suatu partnership, dengan bisnisman, dan bukannya dengan meminjamkan modal dengan menarik bunga.

Para pelopor pemikiran ini mengatakan bahwa dengan "menunggu" atau dengan "menahan diri" dalam suatu periode tertentu dan tidak menggunakan modalnya sendiri untuk memenuhi keinginannya sendiri, kreditor memberikan "waktu" kepada peminjam untuk menggunakan modalnya untuk memperoleh keuntungan. "Waktu" itu sendiri mempunyai "harga" yang meningkat sejalan dengan periode waktu. Jika peminjam tidak diberikan batasan waktu untuk mendapatkan keuntungan dari penggunaan modal yang dipinjamnya, ia tidak akan mampu memperoleh keuntungan dan bahkan 
seluruh bisnisnya bisa hancur karena kekurangan moodal. Masa dimana peminjam menginvestasikan modalnya, mempunyai "harga" tertentu baginya dan ia akan menggunakannya untuk memperoleh keuntungan. Maka tidak ada alasan mengapa kreditor tidak boleh menikmati sebagian dari keuntungan peminjam. Selanjutnya, mereka mengatakan bahwa kemungkinan naik turunnya keuntungan sejalan dengan naik turunnya waktu dan tidak ada alasan mengapa kreditor lidak boleh mengenakan harga (wailu) sesuai dengan lamanya waktu.

Tetapi lagi-lagi pertanyaan bagaimana dan darimana sumbernya kreditor itu mendapatkan informasi bahwa peminjam itu nyata-nyata memperoleh keuntungan dan tidak mengalami kerugian dengan investasi modal pinjamannya itu? Bagaimana ia mengetahui bahwa peminjam itu akan memperoleh keuntungan yang pasti sehingga dengan begitu ia menetapkan bagian keuntungan tersebut? Dan bagaimana dapat memperhitungkan bahwa peminjam pasti akan memperoleh keuntungan yang begitu banyak selama masa modal digunakannya sehingga ia akan mampu membayar harga tertentu secara pasti setiap bulan atau setiap tahun? Para pendukung teori bunga ini tidak mampu memberikan jawaban yang masuk akal terhadap masalah tersebut

Sebuah pendapat menegaskan "produktivitas modal" sebagai jumlah yang diwariskan yang memungkinkan kreditor menarik suatu imbalan (dalam bentuk bunga) dari peminjam atas penggunaan modal tersebut. Ada beberapa ahli ekonomi yang menekankan aspek fungsi modal tersebut dalam produksi. Menurut pandangan tersebut, modal dikatakan 'produktif. Secara jelas ini berarti bahwa "terdapat suatu pasaran terhadap jasa mesin produktif (modal) dan bentuk konkrit modal itu sendiri". Pendapat ini memandang bahwa modal adalah produktif yang dapat diartikan bahwa modal mempunyai daya untuk menghasilkan barang yang jumlahnya lebih banyak daripada yang dapat dihasilkan tanpa modal itu, atau modal mempunyai daya untuk menghasilkan tanpa modal tersebut, atau bahwa modal mempunyai daya untuk menghasilkan nilai tambah danpada nilai yang telah ada itu sendiri. Dan bunga merupakan imbalan atas pelayanan produktif tersebut atas modal kepada peminjam dalam proses produksi.

Tetapi pemyataan bahwa produktivitas merupakan kualitas yang melekat modal adalah tidak beralasan karena modal menjadi produktif hanya apabila digunakan untuk bisnis yang dapat mendatangkan keuntungan oleh seseorang. Apabila modal digunakan untuk tujuan-tujuan konsumsi, maka modal tidak mempunyai kualifikasi semacam itu.

Meskipun modal digunakan dalam usaha-usaha yang mendatangkan keuntungan, tidak perlu kiranya menghasilkan nilai lebih. Dapat dinyatakan bahwa produktivitas tersebut merupakan kualitas yang melekat pada modal. Sering terjadi, terutama dalam keadaan ekonomi yang merosot, penanaman modal tidak hanya menipiskan keuntungan tetapi ternyata melibatkan keuntungan menjadi kerugian.

Jika modal dianggap memiliki produktivitas, produktivitas tersebut tergantung pada berbagai faktor yang lain. Penanaman yang dapat mendatangkan keuntungan banyak tergantung pada tenaga kerja, kemampuan, pandangan yang jauh dan pengalaman orang yang menggunakannya disamping kestabilan ekonomi, sosial dan politik suatu negara. Faktor-faktor tersebut dan faktor-faktor sejajar yang lain merupakan syarat bagl penana nan modal yang dapat mendatangkan keuntungan. Apabila persyaratan tersebut tidak terpenuhi, keuntungan yang diharapkan dari 
penanaman modal tersebut berubah menjadi kerugian.

Jika diakui bahwa modal itu memiliki suatu kualitas produktivitas yang diberikan kepada pemilik modal sebagai bagian keuntungan, tidak ada cara untuk mengetahui secara tepat dan pasti jumlah yang sebenarnya dari keuntungan yang dibayarkan setiap bulan atau setiap tahun. Di samping itu, tidak ada metode untuk menghitung atau memperkirakan keuntungan dari penggunaan modal untuk jangka waktu sepuluh atau dua puluh tahun yang akan datang sehingga memungkinkan untuk dapat menetapkan jangka waktu bunga.

Karena demikian halnya, tidak adil kiranya mengenakan sejumlah bunga terhadap sejumlah uang yang dipinjamkan di muka untuk jangka waktu sepuluh atau dua puluh tahun jika besarnya keuntungan aktual yang dapat diperoleh di masa yang akan datang. tidak diketahui.

Teori nilai barang di masa mendatang lebih rendah dibanding nilai barang di masa sekarang. Beberapa ahli ekonomi berpendapat bahwa manusia pada dasarnya lebih mengutamakan kehendaknya di masa sekarang serta kepuasan sekarang daripada yang akan datang. Para ahli tersebut menjelaskan fenomena bunga dengan suatu rumusan yang sangat dikenal dengan "menurunkan nilai barang di waktu mendatang dibanding dengan nilai barang di waktu kini." Singkatnya, bunga dapat dianggap sebagai agio yang diperoleh dari barang-barang pada waktu sekarang terhadap perubahan atau penukaran barang di waktu yang akan datang. Boehm, pendukung penting dari pendapat ini, memberikan tiga alasan terhadap penurunan nilai di waktu yang akan datang:

1. Keuntungan di masa yang akan datang diragukan karena ketidakpastian peristiwa yang akan datang serta kehidupan manusiar sedangkan keuntungan pada masa kini jelas dan pasti.

2. Kepuasan terhadap kehendak atau keinginan masa kini lebih bernilai bagi manusia daripada kepuasan mereka di waktu yang akan datang karena mungkin mereka tidak mempunyai kehendak semacam itu di waktu yang akan datang.

3. Oleh karena dalam kenyataannya barangbarang pada waktu kini lebih penting dan berguna, dengan demikian barang-barang tersebut mempunyai nilai yang lebih tinggi dibanding dengan barang-barang di waktu yang akan datang.

Berdasarkan alasan-alasan tersebut, mereka mengatakan bahwa keuntungan pasti masa kini sudah jelas diutamakan daripada keuntungan di masa yang akan datang. Oleh karena itu, modal yang dipinjamkan kepada peminjam sekarang memiliki nilai yang lebih tinggi daripada sejumlah uang yang dikembalikan beberapa tahun kemudian. Sesungguhnya, bunga merupakan nilai kelebihan yang ditambahkan pada modal yang dipinjamkan pada masa pembayarannya mempunyai nilai yang sama dengan modal pinjaman semula. Dengan perkataan lain, bunga adalah sama dengan perbedaan dari segi psikologis dan bukannya dari segi ekonomis antara barang-barang masa kini dengan barang-barang di masa yang akan datang.

Apa yang menjadi pertanyaan adalah: apakah sifat manusia sungguh-sungguh menganggap kehendak masa sekarang lebih penting dan berharga daripada keinginankeinginannya di masa yang akan datang? Jika demikian, lalu mengapa banyak orang tidak membelanjakan seluruh pendapatannya sekarang tetapi senang menyimpan pendapatannya itu untuk keperluan di masa yang akan datang? Kita akan 
banyak menjumpai orang yang menahan keinginannya masa kini demi untuk keinginan masa depan yang merupakan peristiwa yang tidak dapat dilihat dan disangka. Segala usaha manusia kini diarahkan untuk masa depan yang lebih baik, sehingga kemungkinan kehidupan manusia di masa yang akan datang lebih bahagia dan sejahtera. Sangat sulit bagi kita untuk menemukan orang yang secara suka rela menciptakan hari ini yang lebih bahagia dan sejahtera dengan mengorbankan kebahagiaan dan kesejahteraannya di masa depan.

Jika sementara kita dapat jumpai orang secara sukarela mengorbankan kebahagiaan masa depan demi memperoleh kesenangan masa kini, sekali lagi rumusan yang diambil untuk menetapkan bunga adalah salah. Menurut rumusan ini, antara peminjam dengan pemberi pinjaman menunjukkan bahwa $£ 100$ hari ini adalah sama dengan $£ 105$ ( $£ 5$ sebagai bunga) setahun mendatang. Ini berarti bahwa setelah lebih dari setahun $£ 105$ akan mempunyai nilai sama dengan $£ 100$ dari tahun sebelumnya. Jika pinjaman tidak dibayarkan setelah satu tahun, setelah dua tahun, $£ 100$ dua tahun yang lalu nilainya akan sama dengan $£ 110$.

Apakah perbandingan antara nilai yang lalu dengan nilai sekarang tersebut benar-benar sesuai? Dan apakah rumusan itu valid bahwa barang masa lalu yang semakin tua, nilainya dibanding dengan nilai barang masa kini akan bertambah? Tidak ada jawaban yang meyakinkan terhadap pertanyaan-pertanyaan tersebut? Maulana Maududi menjelaskan akan bahaya dan kejahatan institusi bunga dan menunjukkan bagaimana bunga itu dapat menyengsarakan dan menghancurkan masyarakat. Sekarang kita akan membicarakan kejahatan-kejahatan moral, budaya dan ekonomi tersebut satu persatu.

Sejatinya, hal yang harus dilakukan adalah bagaimana proses sosialisasi yang dapat menyentuh ranah kesadaran seseorang yang timbul dari diri sendiri tanpa ada paksaan dari pihak manapun. Sosialisasi adalah proses edukasi anggota masyarakat untuk mengenal dan memahami sistem, tata nilai dari budaya yang berlaku di masyarakat (W.J.S. Poerwadarminta, 1990: t.h). Pengenalan dan pemahaman itu akan menjadi sempurna apabila mencakup semua latar belakang timbulnya sistem. Sebagaimana diungkap Max Weber, memahami masyarakat sebenarnya bagaimana cara kita memahami tindakan sosial antar hubungan sosial, dimana "tindakan yang penuh arti" itu ditafsirkan untuk sampai pada penjelasan kausal (George Ritzer, Sosiologi, Ilmu Pengetahuan Berparadigma Ganda, terj. Alimandan, (Jakarta: Jakarta, 1985), hal. 15-42). Dengan demikian, sebenarnya bahwa kultur bisa dicipta, kultur tidak terbentuk secara natural. Kultur dibangun atas dasar konsensus nilai-nilai yang berkembang di mayasarakat dan digerakkan oleh kesadaran universal.

Saat ini, sosialisasi ekonomi dan perbankan syariah dilakukan hanya sebatas simbolik. Indikasinya terlihat dari begitu gencarnya mem-blow up simbol-simbol religi yang bersifat properti. Meskipun hal itu, tidak dianggap tidak penting, signifikansinya hanya sebatas pencitraan saja (brandimage). Sosialisasi seperti ini tidak akan pernah bisa merubah pola pikir (mindset), sikap-perilaku, ideologi, dan menggerakkan kesadaran masyarakat untuk aktif partisipatif mengembangkan ekonomi syariah. Formulasi sosialisasi hendaknya diorientasikan pada proses penyelarasan dan internalisasi nilai-nilai syariah ke dalam nilainilai kearifan kultur lokal yang diyakini dapat mendorong terjadinya perubahan pola pikir (mindset), sikap, ideologi masyarakat secara utuh dalam memahami ekonomi syariah, khusunya perbankan syariah. 


\section{PENUTUP}

Eksistensi perbankan syariah sebagai sebuah institusi bisnis yang merepresentasikan eksistensi ekonomi syariah tidak bisa terlepas dari kehidupan sosial masyarakat. Hal yang sering terlupakan dalam pembangunan institusi bisnis adalah kurangnya pemahaman terhadap kearifan kultur lokal di mana institusi bisnis itu berada. Dan ekonomi syariah (bank syariah) merupakan bagian dari entitas bisnis itu sendiri. Pemahaman atas kultur masyarakat yang menyimpan sejuta kearifan lokal merupakan salah satu faktor signifikan sebagai prasyarat untuk mendesain, menyelaraskan dan mengembangkan bisnis yang dijalankan. Dengan demikian, suatu institusi bisnis tidak hanya berorientasi perusahaan (corporate oriented) tetapi, ia mempunyai keselarasan sosio-kultur dan tanggung jawab sosial (coorporate social responsibility)

Nilai-nilai solidaritas sosial, bagi hasil, kerjasama-kemitraan, etos kerja merupakan sedikit contoh dari kearifan kultur lokal yang telah lama hidup mengakar dalam tradisi masyarakat. Dengan demikian, ikhtiar akselerasi pengembangan perbankan syariah sejatinya tidak hanya difokuskan pada pengeksploitasian simbol-simbol religi yang bersifat properti. Proses internalisasi kearifan kultur lokal dalam sistem perbankan syariah menjadi sebuah paradigma baru dalam pengembangan perbankan syariah. Karena di dalamnya terdapat keluhuran nilai-nilai yang memiliki persenyawaan dan keselarasan dengan prinsip-prinsip syariah.

Oleh karena itu, dengan berbagai pertimbangan yang serius, dapat direkomendasikan hal-hal sebagai berikut:

Pertama, UIN dan IAIN adalah bagian terpenting dan penyandang taklif dalam penyiapan sumber daya manusia yang siap berkompetisi dalam transformasi budaya era globalisasi dan liberalisasi ekonomi; meningkatkan kesiapan pisik dan mental untuk bekerjasama antar ahli dalam merumuskan konsepsi dan praksis ekonomi dan perbankan syariah.

Kedua, UIN dan IAIN menyebarkan dan mensosialisasikan gagasan-gagasan, konsepkonsep dan praktek perekonomian ummatik pada setiap lapisan masyarakat.

Ketiga UIN dan IAIN menyusun rencana pelembagaan akademik dalam upaya menyiapkan sumber daya manusia yang siap berkompetisi.

Keempat, UIN dan IAIN menyiapkan salah satu bentuk otonomi kampus ialah kesiapan self financing kampus melalui pemberdayaan sumber daya manusia yang memiliki budaya kerja dan etos kerja yang tinggi untuk berdiri di atas kaki sendiri dalam memenuhi kebutuhan ekonominya sendiri.

\section{DAFTAR KEPUSTAKAAN}

Mujahidin, Akhmad. 2013. Ekonomi Islam, Sejarah, Konsep, Instrumen, Negara dan Pasar Jakarta: Rajagrafindo Persada.

Al Syafi'i, Abdurrahman bin Abd al Salam. 2005. Nuzhat al Majalis wa Muntakhab al

Nafais, Beirut: Dar al-Kutub al Ilmiyyah.

Hijazi, 'Abd al-Hayyi. 1987. Dirasat al-'Ulum alQanuniyyah, 1 Beirut: Dar al-Fikr.

Taj, 'Abd al-Rahman. 1953. al-Siyasah alShar'iyyah wa al-Figh al-Islami Mesir: Matba' at Dar al-Ta'lif.

Khallaf, 'Abd al-Wahhab. 1977. al-Siyasah alShar'iyyah, Kairo: Dar al-Ansar.

Azra, Azyumardi. 1993. Jaringan Ulama, Bandung: Mizan.

Rofiq, Ahmad. 1995. Hukum Islam di Indonesia, Jakarta: Rajagrafindo Persada. 
Johnson, Doyle Paul. 1988. Sosiologi Klasik dan Modern, Jakarta: Gramedia.

Ritzer, George. 1985. Sosiologi, Ilmu Pengetahuan Berparadigma Ganda, terj. Alimandan, Jakarta: Rajawali.

Drewes, G.W.J. 1989. "Pemahaman Baru Tentang Kedatangan Islam Di Indonesia," dalam, Islam di Asia Tenggara, Jakarta: LP3ES, 1989)

Nasution, Harun. 2002. Teologi Islam AliranAliran Sejarah Analisa Perbandingan, Jakarta: UI Press.

Hasjmy. 1990. Sejarah Kebudayaan Islam Di Indonesia, Jakarta: Bulan Bintang.

Mardjono, Hartono. 1997. Menegakkan Syari'at Islam Dalam Konteks Keindonesiaan, Bandung: Mizan.

SA, Ichtijanto. 1996. Prospek Peradilan Agama Sebagai Peeradilan Negara Dalam Sistem Politik Hukum di Indonesia, dalam, Amrullah Ahmad, Dimensi Hukum Islam Dalam Sistem Hukum Nasional Jakarta: Gema Insani Press.

Khaldun, Ibnu. 1986. Muqaddimah Ibn Khaldun, Terjemahan Ahmadie Thoha, Jakarta: Pusataka Firdaus.

Al-Jawziyyah, Ibn Qayyim. t.th. I'lam alMuwaqi'in 'an Rabb al-'Alamin, 3, Beirut: Dar al-Jayl.

Praja, Juhaya S. 1994. Hukum Islam, Pemikiran dan Praktek. Bandung: Remaja Rosdakarya.
Syaltut, Muhamad. 1959. Akidah wa al-Syari'ah, Beirut: Dar al-Fikri, 1959), cet ke-1.

Ali, Muhammad Daud. 1997. “Kedudukan Dan Pelaksanaan Hukum Islam Dalam Negara Republik Indonesia," dalam, Hukum Islam Dalam Tatanan Masyarakat Indonesia, Jakarta: Logos.

Muchsin, Hukum Islam Dalam Perspektif dan Prospektif(Surabaya: Al-Ikhlas, 2003),

Djatnika, Rachmat. 1991. "Sosialisasi Hukum Islam di Indonesia", dalam, Abdurrahman Wahid, Konstribusi Pemikiran Islam di Indonesia, Bandung: Remaja Rosdakarya.

Redaksi Sinar Grafika. 1999. Amandemen UUD 1945, Jakarta: Sinar Grafika.

Sucipto, "Tinjauan Kritis Terhadap Pembangunan Hukum Indonesia" dalam, Analisis CSIS, No. 1, (JanuariFebruari, 1993)

Amal, Taufik Adnan. 1994. Islam dan Tantangan Modernitas: Studi Atas Pemikiran Fazlur Rahman, Bandung: Mizan.

Poerwadarminta, W.J.S. 1990. Kamus Umum Bahasa Indonesia, Jakarta: Balai Pustaka.

Mahendra, Yusril Ihza. 1996. Dinamika Tatanegara Indonesia Kompilasi Aktual Masalah Konstitusi Dewan Perwakilan dan Sistem Kepartaian, Jakarta: Gema Insani Press. 